\title{
In vitro biology of pigeon louse Colpocephalum turbinatum (Amblycera: Phthiraptera)
}

\author{
Satyapal Singh Rana \\ Department of Zoology, Shaheed Mangal Pandey Govt. Girls P.G. College, Meerut, \\ (U.P.), India \\ S. K. Bhardwaj \\ Department of Zoology, CCS University Meerut, (U.P.), India \\ Arun Kumar Saxena* \\ Department of Zoology, Govt. Raza P.G. College Rampur, (U.P.), India \\ *Corresponding author. E-mail:akscsir@rediffmail.com
}

\begin{abstract}
In vitro rearing of amblyceran Phthiraptera is a challenging task. A look on the literature reveals that negligible information exists on the in vitro bionomics of avian Amblycera. Present report furnishes information on the in vitro biology of an amblyceran louse, Colpocephalum turbinatum, reared at $35 \pm 1{ }^{\circ} \mathrm{C}, 75-82 \%$ Relative Humidity, at feather diet. The incubation period of the eggs of louse was determined as $5.37 \pm 0.67$ days. The duration of first, second and third nymphal instars remained $5.04 \pm 0.65,5.12 \pm 0.89$ and $5.0 \pm 0.57$ days, respectively. The longevity of adult female (13.04 \pm 3.67 days) was comparatively longer than that of males (9.6 \pm 2.87 days). An adult female laid an average of $0.63 \mathrm{egg} /$ day in vitro condition $\left(35 \pm 1^{\circ} \mathrm{C}\right.$ and $75-82 \% \mathrm{RH}$, at feather diet).
\end{abstract}

Keywords: Amblycera, Biting lice, Colpocephalum turibinatum, Pigeon louse, Phthiraptera.

\section{INTRODUCTION}

Information on the bionomics of the parasitic insects is useful for complete understanding of its biology and its adaptation in surroundings. It further helps in realizing the impact of parasitism and determining the eradication measure. Since, it is difficult to rear single louse or its colonies on natural host, the in vitro rearing has emerged as tool for deriving information on the life cycle of avian lice. During last 15 years selected workers have used the incubation period of eggs, duration of nymphal instars, adult longevity and rate of egg production (derived through in vitro studies) to construct the life table of certain ischnoceran Phthiraptera. (Beg et al., 2005; Saxena et al., 2007; Gupta et al., 2007; Arya et al., 2009; Agarwal et al., 2011; Singh et al., 2012; Kumar and Hasan, 2014). In vitro culturing of different species belonging to genus Bovicola (mammalian Ischnocera, infesting goats) have been more successfully performed (Rashmi et al., 2010).

Survey of literature indicates that the bionomics of only one amblyceran Phthiraptera (chicken body louse, Menacanthus stamineus) has been recorded in vitro condition (Stockdale and Raun, 1965). Another amblyceran louse, Colpocephalum turibinatum (infesting pigeons) has been colonized in

\section{Article Info}

DOI:10.31018/jans.v10i2.1776 Received: January 13, 2018 Revised: April 6, 2018 Accepted: May 17, 2018

\section{How to Cite}

Rana, S.S. et al. (2018). In vitro biology of Pigeon louse Colpocephalum turbinatum (Amblycera: Phthiraptera). Journal of Applied and Natural Science, 10(2): 770 - 772 vitro condition by Nelson (1971). However, attempt to record the data on bionomics of the amblyceran louse has yet not been made. In the present study, C. turbinatum has been reared to observe the incubation period of the eggs, duration of nymphal instars, adult longevity and egg production rate of the louse in vitro condition.

\section{MATERIALS AND METHODS}

For in vitro experimentation on C. turbinatum, the eggs (glued to feathers), different nymphal instars and healthier adults of the louse were obtained from lousy pigeons (Columba livia). Sixty eggs (glued to suitably trimmed feathers) were reared at $35 \pm 1{ }^{\circ} \mathrm{C}$ in glass petridishes. Thirty nymphs (each stage) and sixty adults were reared in beakers (without spout) /battery jars, containing 50-100 $\mathrm{ml}$. saturated solution of Sodium Chloride and Potassium Chloride, for maintaining the Relative Humidity. After lining the culture vials with filter paper, a layer of suitably chopped feathers (belonging to popular resting sites i.e. vent wings and tail) were arranged along the sides of vials. Culture vials were reared in incubator at the intended temperature $\left(35 \pm 1^{\circ} \mathrm{C}\right)$ and examined daily. The number of survivors and the numbers of eggs laid were recorded daily and the mean values were determined in accordance with Saxena 
Rana S.S. et al. / J. Appl. \& Nat. Sci. 10 (2): 770 - 772 (2018)

et al. (2007) and Gupta et al. (2007).

\section{RESULTS AND DISCUSSION}

60 eggs of $C$. turbinatum were incubated at $35 \pm 1^{\circ} \mathrm{C}$ and $75-82 \% \mathrm{RH}$ (in two batches). Fresh eggs of $C$. turbinatum are pearly white in appearance and turn yellowish brown after two days. Three eggs hatched on $4^{\text {th }}$ day, 32 on $5^{\text {th }}$ day, 18 on $6^{\text {th }}$ day and 3 on $7^{\text {th }}$ days. Eggs were incubated till $12^{\text {th }}$ day and those failing to hatch were regarded as dead. Thus, the average incubation period of the eggs of $C$. turbinatum appeared to be $5.37 \pm 0.67$ days (range 4-7 days, $n=56$ ) (Fig. 1). The mortality at egg stage remained $6.7 \%$.

Out of 30 first instars reared, 03 moulted on $4^{\text {th }}$ day, 16 on $5^{\text {th }}$ day, 2 on $6^{\text {th }}$ day and 02 on $7^{\text {th }}$ day. The mean duration of first nymphal instars was $5.04 \pm 0.65$ days (range, $4-7$ days; $n=22$ ). Mortality at first instars stage was $26.7 \%$. Likewise, out 30 second instars reared, 04 moulted on $4^{\text {th }}$ day, 16 on $5^{\text {th }}$ day, 02 on $6^{\text {th }}$ day, one each on $7^{\text {th }}$ and $8^{\text {th }}$ day. Thus, the mean value of the duration of second instars was $5.12 \pm 0.89$ days (range, 4-8 days, $n=24$ ) (Fig. 1). Mortality at second instars stage was $20 \%$. Out of 30 third instars reared, 04 moulted on $4^{\text {th }}$ day, 17 on $5^{\text {th }}$ day and 4 on $6^{\text {th }}$ day. The mean duration of third instars was $5.0 \pm 0.57$ days (range 4-6 days, $n=25$ ). The mortality at third instars stage was $16.7 \%$.

Sixty adults (30 adult males and 30 adult females) were reared (in two batches) in glass beakers (without spout/ battery jars), till the survival of last adult (at $35 \pm 1{ }^{\circ} \mathrm{C}, 75-82 \% \mathrm{RH}$, at a feather diet). The average longevity of adult males was recorded as 9.6 2.87 days (range 1-16 days, $n=30$ ). The lifespan of adult females remained slightly longer than the adult males (13.04 \pm 3.67 days; range $2-18$ days; $n=30$ ). A sum of 172 eggs was laid by the females (indicating the rate of egg production as 5.7 eggs/ female during lifespan and 0.63 eggs/ female/day).

Selected workers have performed in vitro rearing of ischnoceran lice infesting avian and mammalian hosts. Ischnoceran phthirapteran can be comparatively easily reared as they are sluggish in nature and feed on feather derivatives or skin scrapings. On the other hand, amblyceran Phthiraptera are very active and fast running lice and pose difficulties in handling during in vitro experimentations. Moreover, most of them are haemetophagous in nature and can be successfully reared by fulfilling their dietary requirements. Stockdale and Raun (1965) has reared an amblyceran poultry louse, Menacanthus stramineus (at $35{ }^{\circ} \mathrm{C}, 95 \% \mathrm{RH}$, and at feather diet) and determined the incubation period of its eggs (4.5 days), duration of three nymphal instars (3.0, 3.0 and 3.0 days, respectively) and the egg rate (1.6/female/ day). In contrast, C. turbinatum exhibited slightly longer incubation period and duration of nymphal

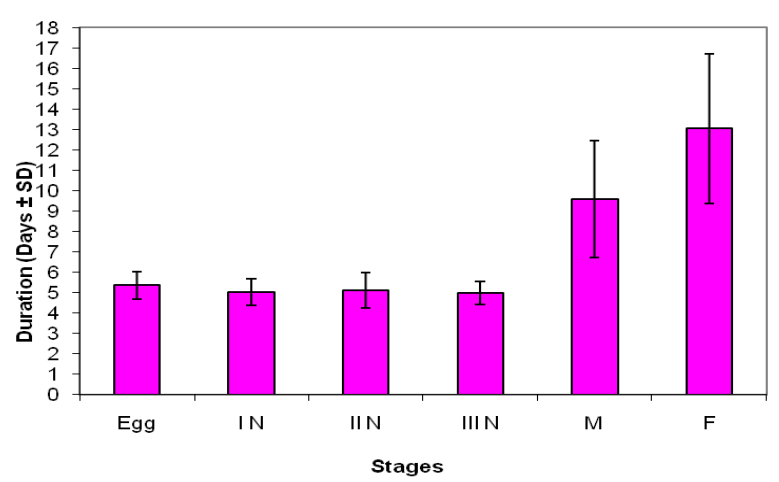

Fig.1. Showing duration of egg, nymphal instars (first, second and third) and adults (male and female) of Colpocephalum turbinatum reared at $35 \pm 1^{\circ} \mathrm{C}, 75-82 \% \mathrm{RH}$, at feather diet.

instars, but exhibited lower egg rate $(0.63 \mathrm{egg} /$ female/day) in vitro condition $\left(35 \pm 1{ }^{\circ} \mathrm{C}, 75-82 \%\right.$ $\mathrm{RH}$, at feather diet). Maximum survival of C. turbinatum has been recorded as 18 days during the present study. A look on the literature reveals that the incubation period of eggs of avian Ischnocera varies from 4.2 (Lipeurus lawrensis tropicalis; Saxena et al. 1991) to 8.0 days (Falcolipeurus frater, Agarwal, 1967). The duration of nymphal instars varies from 5.7 (Goniocotes gallinae; Saxena et al. 2007) to 10.7 days (Lipeurus tropicalis; Arora and chopra, 1959). The longevity of adults varies from 8.2 (Philopterus lahorensis; Beg et al. 2005) to 34.0 days ( Goniodes colchici; Williams, 1970). Likewise, daily egg rate of avian Ischnocera varies from 0.4 (Columbicola columbae; Singh et al. 2001) to 2.0 per day (Lipeurus lawrensis tropicalis; Saxena et al. 1991). In case of mammalian Ischnocera, the incubation period of eggs varies from 6.9 (Bovicola caprae; Kumar et al. 1993) to 10.1 days (Bovicola crassipes; Hopkins and Chamberlain, 1969). Likewise, duration of nymphal instars of mammalian Ischnocera varies from 5.3 to 8.02 days (Bovicola limbata; Hopkins and Chamberlain, 1969). The longevity of adult mammalian Ischnocera varies from 15.2 days (Bovicola caprae; Kumar et al., 1993) to 49.2 (Bovicola ovis; Hopkins and Chamberlain, 1972). Likewise, the daily average egg rate varies from 0.7 (Bovicola caprae; Kumar et al. 1993) to 1.2 per day (Bovicola crassipes; Hopkins and Chamberlain, 1969). Thus, the average incubation period of eggs, duration of nymphal instars, adult longevity and the egg rate of $C$. turbinatum conforms to the avian and mammalian Ischnocera studied, so far.

\section{Conclusion}

Avian Amblycera are difficult to handle during in vitro experimentations, due to their active habits. A look on the literature reveals that negligible information exists on the in vitro bionomics of amblyceran Phthiraptera. Keeping in view the lacau- 
na prevailing in the field an amblyceran pigeon louse was subjected to in vitro experimentation. The present report provides information on the incubation period of the eggs, duration of nymphal instars, adult longevity and the egg rate of Colpocephalum turbinatum.

\section{ACKNOWLEDGEMENTS}

Authors are thankful to Principal, Shaheed Mangal Pandey Govt. Girls P.G. College, Meerut and the Head, Department of Zoology, CCS University, Meerut for providing laboratory facilities.

\section{REFERENCES}

Agarwal (1967). Studies on the bionomics and lifehistory of Falcolipeurus frater (Giebel : 1874) (Mallophaga : Ischnocera). Indian J. Zootomy. 8 (1): 21-40.

Agarwal, G. P., Ahmad, A., Rashmi, A., Arya, G., Bansal, N. and Saxena, A. K. (2011). Bio-ecology of the louse, Upupicola upupae infesting common Hoopae, Upupa epops. J. Insect Sci. 11:1-9.

Arora, G. L. and Chopra, N. P. (1959). Observation on life history of Lipeurus tropicalis Peters (Mallophaga : Ischnocera). Res. Bull. Punjab Univ. 10(2):179-187.

Arya, G., Bansal, N., Ahmad, A., Rashmi, A. and Saxena, A. K. (2009). Population expansion of the Common Baya louse, Brueelia plocea (Lakhsminarayana, 1968) (Phthiraptera: Ischnocera). Rev. Ibero-Latinoam. Parasitol. 68 (2):192-195.

Beg, S., Kumar, S., Gupta, N., Khan, V. and Saxena, A. K. (2005). Life table of Philopterus lahorensis (Phthiraptera: Mallophaga) infesting crows. Rivista Iber. de Parasitol. 65 (1-4): 63-66.

Gupta, N., Kumar, S. and Saxena, A. K. (2007). Intrinsic rate of natural increase of Brueelia amandavae (Ischnocera, Phthiraptera) infesting Indian Red Adavat. Biologia, 62 (4): 458-461.

Hopkins, D. E. and Chamberlain, W. F. (1969). In vitro colonization of the goat biting lice, Bovicola crassipes and B. limbata. Ann. Ent. Soc. Amer. 62: 826-828.
Hopkins, D. E. and Chamberlain, W. F. (1972). Sheep bitting louse : Notes on the biology of lice reared off the host. Ann. Ent. Soc. Amer. 65(5):1182-1184.

Kumar, A., Rawat, B. S. and Saxena, A. K. (1993). In vitro biology of goat biting louse, Bovicola caprae Gurlt (Phthiratpera : Ischnocera). Bioved, 4(2):277282.

Kumar, V. and Hasan, S. S. (2014). In vitro bionomics of an Ischnoceran louse, Lipeurus caponis (Phthiraptera : Insecta). J. Parasit. Dis. DOI 10.1007/s 12639-014-01512-9

Nelson, B. C. (1971). Successful rearing of Colpocephalum turbinatum (Phthiraptera). Nature (London), 232 (34) : 255

Rashmi, A., Ahmad, A., Bansal, N. and Saxena, A. K. (2010). Rate of population expansion of goat biting louse Bovicola caprae (Phthiraptera: Ischnocera). Ann. Entomol. 28(1): 21-25

Saxena, A. K., Trivedi, M. C., Rawat, B. S. and Kumar, A. (1991). Bionomics of poultry louse, Lipeurus lawrensis tropicalis Peters (Phthiraptera : Ischnocera). J. Zool. Res. 4(1\&2) : 27-32.

Saxena, A. K., Kumar, S., Gupta N. and Singh, R. (2007). Population expansion of poultry fluff louse, Goniocotes gallinae (De Geer, 1778) (Ischnocera Phthiraptera, Insecta). Zool. Sci. 24: 327-330.

Singh, P., Arya, G., Ahmad, A. and Saxena, A. K. (2012). In vitro biology of Columbicola bacillus (Phthiraptera: Ischnocera). J. Appl. \& Nat. Sci. 4 (2):234-236.

Singh, S. K., Kumar, S. and Saxena, A. K. (2001). In vitro biology of a pigeon louse, Columbicola columbae (Phthiraptera : Ischnocera). Prof. V. N. Capoor Commem. vol., S.K. Malhotra and R.S. Chauhan (eds.). Ankit Publications, Allahabad, India, 54-56.

Stockdale, H. J. and Raun, E. S. (1965). Biology of the chicken body louse, Menacanthus stramineus. Ann. Entomol. Soc. Amer. 58(6): 802-805.

Williams (1970). In vitro studies on the environmental biology of Goniodes colchici (Denny) (Mallophago : Ischnocera). III. The effects of temperature and humidity on the uptake of water vapour. Aust. J. Zool. 55:553-568 